1

2

3

4

5

6

\section{Abstract:}

\title{
How to use empirical data to improve transportation infrastructure
} risk assessment

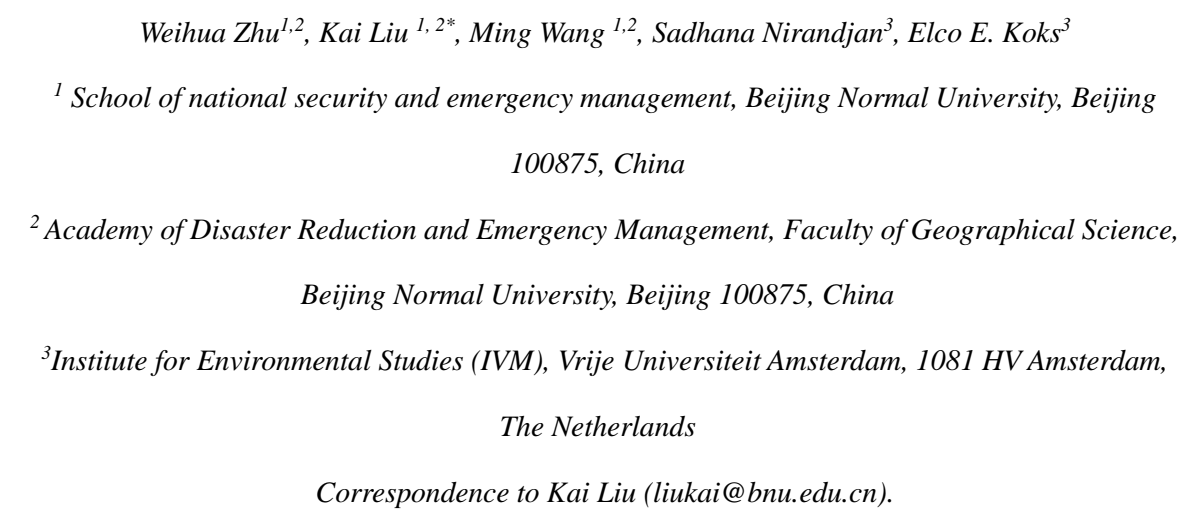

Rainfall-induced hazards, such as landslides, debris flows, and floods cause significant damage to transportation infrastructure. However, an accurate assessment of rainfall-induced hazard risk to transportation infrastructure is limited by the lack of regional and asset-tailored vulnerability curves. This study aims to use multi-source empirical damage data to generate vulnerability curves and assess the risk of transportation infrastructure to rainfall-induced hazards. The methodology is exemplified through a case study for the Chinese national railway infrastructure. In doing so, regional and national-level vulnerability curves are derived based on historical railway damage records. This is combined with daily precipitation data and the railway infrastructure market value to estimate regional- and national-level risk. The results show large variations in the shape of the vulnerability curves across the different regions. The railway infrastructure in Northeast and Northwest China is more vulnerable to rainfall-induced hazards due to low protection standards. The expected annual damage (EAD) ranges from 1.88 
1 to 5.98 billion RMB for the Chinese railway infrastructure, with a mean value of 3.91 billion

2 RMB. However, the risk of railway infrastructure in China shows high spatial differences due

3 to the spatially uneven precipitation characteristics, exposure distribution, and vulnerability

4

5

9 effective decisions to make our infrastructure resilient.

10 Keywords: multi-source empirical data, vulnerability curve, risk estimate, damage

11 length factor

\section{1. Introduction}

In recent years, extreme precipitation events have increased in both frequency and intensity in the context of global warming (Shi et al., 2018; Cardoso Pereira et al., 2020; Li et al., 2020). Extreme precipitation may generate landslides, debris flows, and floods, which have the potential to damage transportation infrastructure and disrupt transportation functions, thereby posing a severe threat to the economy and society (Pregnolato et al., 2017; Diakakis et al., 2020; Petrova, 2020). In July 2021, Zhengzhou was hit by a heavy downpour, that reached a cumulative precipitation of $617.1 \mathrm{~mm}$ in three days. The associated flash floods resulted in the destruction of the Zhengzhou metro system; suspension of more than 80 bus lines; damage to 67 urban bridges, culverts and tunnels; cancellation and delay of more than 200 flights from 
1 Zhengzhou airport; and flooded lines, collapsed roadbeds, and waterlogging of equipment

2 forcing railway operators to shut down for several days (Fig. 1a). On May 23, 2010, a landslide

3 occurred in the Yujiang-Dongxiang section of the Shanghai-Kunming Railway in Jiangxi

4 Province, causing the derailment of passenger train K859 (Fig. 1b). The sliding body was 60

5 metres long, 30 metres wide, and 3-8 metres thick, resulting in a volume of approximately 9,000

6 cubic metres. The cumulative precipitation in the 11 days before the incident was $251.5 \mathrm{~mm}$ in

7 Xiaogang town, Dongxiang County. In China, the average annual direct damage of railway

8 infrastructure caused by rainfall-induced hazards was approximately 3.29 billion RMB from

92000 to 2017 and has increased in recent years (Editorial Board of China Railway Yearbook,

10 2001-2017).

11 (a)
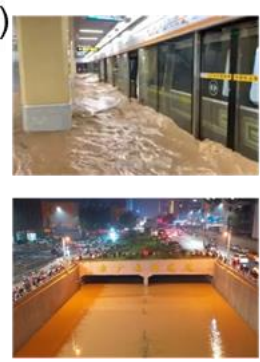
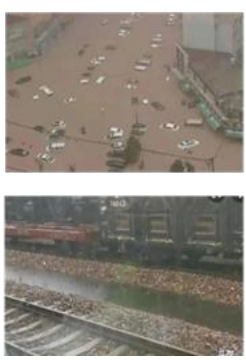

(b)

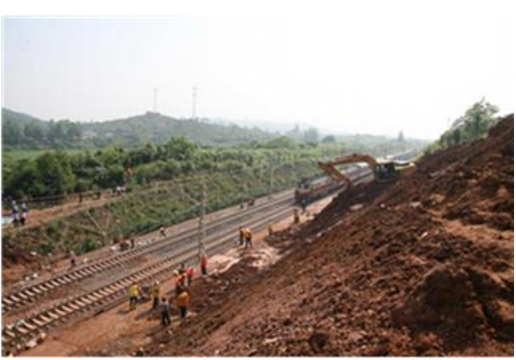

Fig. 1 (a) Transportation infrastructure damaged by floods triggered by extreme precipitation at Zhengzhou, Henan province (2021); (b) Railroad damage by a debris flow triggered by extreme precipitation at Xiaogang, Jiangxi Province (2010).

Accurate assessment of transportation infrastructure damage and risk due to hazards triggered by rainfall is an essential component in transportation infrastructure risk management (Liu et al., 2018a, 2021). In general, transportation infrastructure impacts due to natural hazards include two aspects: (1) direct damage to the structure (Koseki et al., 2012; Kellermann et al., 2015; Koks et al., 2019); and (2) indirect impact to the transportation service and associated 
1 macroeconomic impact (Lamb et al., 2019). Determining direct damage is commonly done

2 using vulnerability curves (Englhardt et al., 2019; Koks et al., 2019), which typically present

3 the damage degree of infrastructure assets that would occur at specific hazard intensities (Jongman et al., 2012; Ward et al., 2013). As the critical link of hazard characteristics and damage loss, few studies (e.g. Sande and C.J, 2001; Kok et al., 2004; Huizinga et al., 2017) tried to work on vulnerability curves for transportation infrastructure assets in different regions.

7 In these studies, empirical and synthetic approaches are usually adopted to develop curves

8 based on damage data (Merz et al., 2010) and expert judgement (Gerl et al., 2016).

9 Unfortunately, due to the lack of detailed damage data, such damage curves are unavailable for

10 most regions. Habermann and Hedel (2018) conducted a literature review on the damage

11 functions for transportation infrastructure due to wildfires and floods. They found that damage

12 functions for the transportation sector are scarce in the literature, and damage curves for the transportation sector in different publications vary in shapes and values.

This article aims to use multi-source empirical damage data to assess the vulnerability and risk of transportation infrastructure associated with rainfall-induced hazards (i.e. landslides, debris flows, and floods). We develop a first set of regional and national vulnerability curves for Chinese railway infrastructure that relates the damage degree of railway assets to precipitation intensities. Based on these vulnerability curves, the risk of the railway

19 infrastructure associated with rainfall-induced hazards is estimated.

20 The remainder of the article is organized as follows. Section 2 describes this work's datasets,

21 including data on precipitation, historical railway damage, yearly railway damage and railway 
1 market value. Section 3 describes the methodological framework, thereby elaborating on the

2 method for: (1) vulnerability assessment, (2) and risk estimation. Section 4 presents the main

3 results. Sections 5 and 6 discuss the results and conclude the article.

\section{2. Data collection}

\section{$5 \quad 2.1$ Precipitation data}

6 The CN05.1 dataset provides information on the observed daily precipitation from 1961 to

72018 at a $0.25^{\circ}$ spatial resolution (Wu and Gao, 2013; Zhang et al., 2019). The dataset is derived

8 from more than 2,400 in situ gauging stations by the Chinese Meteorological Administration

9 (CMA). The CN05.1 product has been recognized to be more reliable than its previous versions

10 because of the inclusion of more ground stations (Yatagai et al., 2009; Zhang et al., 2019). The

11 resolution of the $\mathrm{CN} 05.1$, however, is too coarse to accurately capture local extreme

12 precipitation events. As a complementary precipitation dataset, we therefore extract local

13 precipitation information from multiple news sources for $37 \%$ of the damage records (see

14 section 2.2). These news sources contain precipitation data obtained from rain gauges installed

15 by the railway department, thus measuring local extreme precipitation. 


\section{$1 \quad 2.2$ Historical railway damage by rainfall-induced hazards}

2 (a)

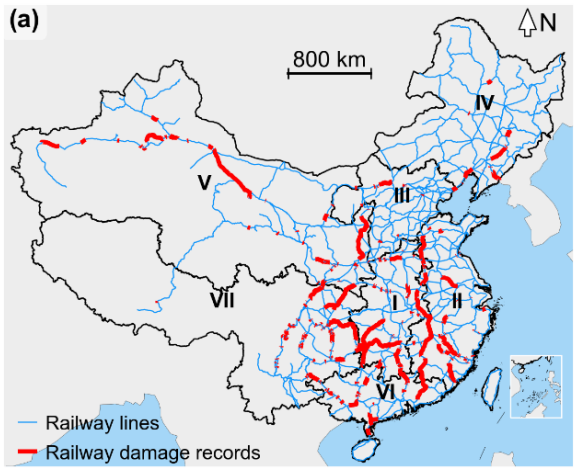

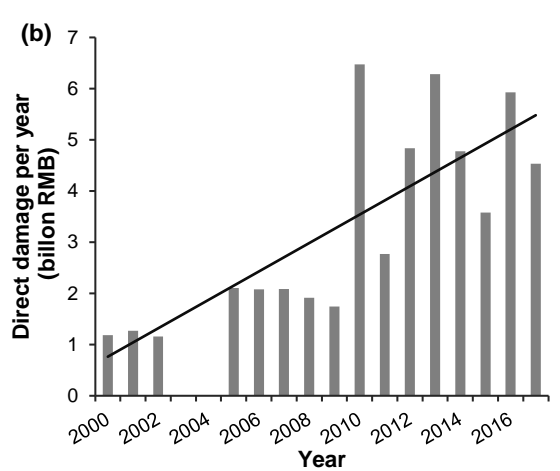

Fig. 2 (a) Spatial distribution of national railway damage records. We divide the mainland of

China into seven geographical divisions: Central China (I), East China (II), North China (III), Northeast China (IV), Northwest China (V), South China (VI), and Southwest China (VII).

(b) Temporal distribution of historical damage to the national railway infrastructure by rainfall-induced hazards from 2000 to 2016. Railway geometries @ OpenStreetMap contributors 2019. Distributed under the Open Data Commons Open Database License (ODbL) v1.0.

Zhao et al. (2020) catalogued 464 railway disasters caused by rainfall-induced hazards in the Chinese railway system between 2000 and 2016. After removing service disruption disasters (i.e. trains that slow down or stop for safety reasons) that are irrelevant for this study, we found a total of 236 railway damage records that represent structural damage to railway assets or debris covering the rail. The spatial distribution of the filtered set of national railway damage records is presented in Fig. 2a. For all these records, we collect information about the occurrence date of the damage, the damage location, and the descriptive damage state by using online publicly available news sources. In this study, if damages induced by a precipitation event occurred in the segment between two adjacent stations, one damage record is counted. 
1 Table 1 gives some typical railway damage records over 1981-2016. The information of the all

2 damage records used in this study can be found in supplement material.

3 Table 1 Typical railway damage records over 1981-2016.

\begin{tabular}{|c|c|c|c|c|}
\hline Damage date & Url & $\begin{array}{c}\text { Railway } \\
\text { name }\end{array}$ & Damag segment & Damage state \\
\hline $2005 / 6 / 21$ & $\begin{array}{c}\text { http://news.sina.com.cn/c/2005- } \\
\text { 06-25/10586266797s.shtml }\end{array}$ & $\begin{array}{l}\text { Yingxia } \\
\text { railway }\end{array}$ & $\begin{array}{l}\text { Panfang- } \\
\text { Yangkou }\end{array}$ & $\begin{array}{l}\text { Geological, } \\
\text { severe }\end{array}$ \\
\hline $2005 / 6 / 21$ & $\begin{array}{c}\text { http://news.sina.com.cn/c/2005- } \\
\text { 06-25/10586266797s.shtml }\end{array}$ & $\begin{array}{l}\text { Yingxia } \\
\text { railway }\end{array}$ & $\begin{array}{l}\text { Xiawangtang- } \\
\text { Shaikou }\end{array}$ & $\begin{array}{l}\text { Geological, } \\
\text { severe }\end{array}$ \\
\hline 2013/7/13 & $\begin{array}{c}\text { http://www.eeb.cn/tabid/372/info } \\
\text { id/1521/frtid/89/default.aspx }\end{array}$ & $\begin{array}{l}\text { Baoxi } \\
\text { railway }\end{array}$ & Yanan-Yananbei & $\begin{array}{c}\text { Embankment, } \\
\text { Moderate }\end{array}$ \\
\hline 2016/7/17 & $\begin{array}{c}\text { https://baike.so.com/doc/244253 } \\
\text { 72-25257771.html }\end{array}$ & $\begin{array}{l}\text { Jiaoliu } \\
\text { railway }\end{array}$ & $\begin{array}{l}\text { Wanyan- } \\
\text { Longbizui }\end{array}$ & Track, severe \\
\hline
\end{tabular}

For the available 236 railway damage records, $84 \%$ occurred in the summer (June, July, and

5 August). Most of the disasters occurred in July, accounting for $40 \%$ of the 236 railway damage

6 records; $30 \%$ and 14\% occurred in June and August, respectively. These numbers correspond

7 to most parts of China's rainy seasons in which precipitation is a crucial trigger of rainfall-

8 induced hazards. Fig. 2a shows the spatial distribution of railway damage for the years 2000-

9 2016. The results show that the national railway lines suffered widespread rainfall-induced

10 damage, especially in South China. Detailed spatial distributions of damages and associated

11 reasons were explored in previous research of Liu et al.(2018) and Zhao et al. (2020). To explore

12 the spatial distribution of railway vulnerability in different regions, China was divided into

13 seven sub-regions based on seven geographical divisions (Liu et al., 2020), as shown in Fig. 2a:

14 Central China (I), East China (II), North China (III), Northeast China (IV), Northwest China 
1 (V), South China (VI), and Southwest China (VII) (Liu et al., 2020).

\section{$2 \quad 2.3$ Railway damage yearly data}

Two datasets are used to obtain railway damage yearly data: the national railway yearbooks (Editorial Board of China Railway Yearbook, 2001-2017) and the Zhengzhou regional administrator's yearbooks (Editorial Board of Zhengzhou Administrator's Railway Yearbook, 2001-2017). The national railway yearbooks cover data on the direct damage, total damage length and the number of total damage events (one damage event is defined as a main railway line is damaged by a precipitation event) per year for the national railway system. The Zhengzhou regional administrator's yearbooks provide information on the number of total damage events and the total number of damaged places (i.e. a continuous section of damage) per year for the Zhengzhou administrator railway system (ZHR), from 2000 to 2017 by rainfallinduced hazards.

An overview of the yearly railway damage obtained from the two sources is shown in Table 2. Fig. 2 b shows the direct damage per year from 2000 to 2017 (missing data in 2003 and 2004); the economic damage significantly increased from 2000 to 2017 , which is due to the increased railway exposure and extreme precipitation events (Zhao et al., 2020). The average annual economic damage is estimated to be 3.29 billion RMB. The ZHR damage data shows that each damage event causes multiple damage places on railway infrastructure, with an average of nine damage places per event. Assuming that the number is the same for the national railway system, we calculate that the average damage length is $753 \mathrm{~m}$ per damage place for an event using the total number of damage events and total damage length at a national level. 
1 Table 2 Railway damage for the period 2000-2017

\begin{tabular}{|c|c|c|c|c|c|}
\hline \multirow[b]{2}{*}{ Year } & \multicolumn{3}{|c|}{ National } & \multicolumn{2}{|c|}{ Zhengzhou Administrator } \\
\hline & $\begin{array}{c}\text { Damage event } \\
\text { times }\end{array}$ & $\begin{array}{c}\text { Damage length } \\
(\mathrm{km})\end{array}$ & $\begin{array}{c}\text { Direct damage } \\
\text { (billon) }\end{array}$ & $\begin{array}{c}\text { Damage event } \\
\text { times }\end{array}$ & Damage places \\
\hline 2000 & 183 & 478.6 & 1.179 & & \\
\hline 2001 & 98 & 358.8 & 1.266 & 42 & 469 \\
\hline 2002 & 106 & 441.1 & 1.156 & 21 & 174 \\
\hline 2003 & 142 & & & 81 & 125 \\
\hline 2004 & 122 & & & 114 & 224 \\
\hline 2005 & 203 & & 2.105 & 36 & 169 \\
\hline 2006 & 128 & 922.8 & 2.073 & 34 & 170 \\
\hline 2007 & 121 & 832.6 & 2.081 & 40 & 247 \\
\hline 2008 & 75 & 802.1 & 1.911 & 7 & 272 \\
\hline 2009 & 86 & 511.1 & 1.741 & 17 & 226 \\
\hline 2010 & 177 & 1066.6 & 6.473 & 20 & 354 \\
\hline 2011 & 109 & 1107.0 & 2.767 & 8 & 144 \\
\hline 2012 & 99 & 1606.0 & 4.833 & 41 & 160 \\
\hline 2013 & 113 & 709.0 & 6.280 & 65 & 144 \\
\hline 2014 & 82 & 654.0 & 4.774 & 52 & 206 \\
\hline 2015 & 91 & 265.0 & 3.576 & 37 & 90 \\
\hline 2016 & 211 & 388.0 & 5.923 & 53 & 246 \\
\hline 2017 & 165 & 488.0 & 4.531 & 37 & 205 \\
\hline
\end{tabular}

\section{$2 \quad 2.4$ Railway market value}

3 The railway market value is from the World Bank Office, China (Gerald Ollivier, 2014).

4 They provide the range of average unit costs for the $200 \mathrm{~km} / \mathrm{h}$ double-track railway (AUC-

5 200D) shown in Table 3. The AUC-200D divides the cost of the railway into five elements, (1) 
1 land acquisition and resettlement, and four first-level structures: (2) civil works (embankment,

2 bridge or trunk), (3) track, (4) signalling, and (5) communications and electrifications. We use

3 the mean value to present the unit cost of the element (e.g. the mean value is 6 million/per $\mathrm{km}$

4 of track element). The average railway market value used in this work is 56 million RMB,

5 which does not consider land acquisition and resettlement costs since those parts were paid

6 before construction.

7 Table 3 Range of average unit costs (RMB million/per km of double track)

\begin{tabular}{|c|c|c|c|c|}
\hline \multicolumn{2}{|c|}{ Element } & \multicolumn{2}{|c|}{$\begin{array}{l}\text { RMB million/per } \\
\text { km of double track }\end{array}$} & $\begin{array}{l}\text { Average unit costs } \\
\text { (RMB million/per km }\end{array}$ \\
\hline $\begin{array}{l}\text { Land acquisition } \\
\text { and resettlement }\end{array}$ & & $5-8$ & & 6.5 \\
\hline \multirow{3}{*}{ Civil Works } & Embankment & $23-28$ & \multirow{3}{*}{$42-43$} & \multirow{3}{*}{42.5} \\
\hline & Bridges/viaducts & $59-62$ & & \\
\hline & Tunnels & $51-68$ & & \\
\hline Track (ballasted) & & $5-7$ & & 6 \\
\hline $\begin{array}{l}\text { Signalling and } \\
\text { communications }\end{array}$ & & $3-4$ & & 3.5 \\
\hline Electrification & & 4 & & 4 \\
\hline
\end{tabular}

\section{3. Methods}

9 Figure 3 presents an overview of the methodological framework used in this study. The

10 methods in this study are divided into two parts: (1) vulnerability assessment and (2) risk

11 estimation. In the first part, national and regional vulnerability curves that characterize the

12 railway susceptibility by relating the damage degree to precipitation intensity are generated. In 
1 the second part of the research, we estimate the risk to the Chinese railway system. The railway

2 market value is combined with the vulnerability curve developed in the first part of the research

3 and spatial data on the precipitation intensity to calculate the risk represented by expected

4 annual damage (EAD).

\section{$9 \quad$ 3.1 Vulnerability curve estimation}

\section{$10 \quad$ 3.1.1 Precipitation intensity estimated for damage records} the news are shown in Fig. 4a with red lines. For each remaining damage record, we use the maximum 1-day precipitation amount along the damaged segment in the five consecutive days

14 (M1-5d) before the damage occurred to present the precipitation intensity, shown in Fig. 4a 
1 with black lines. To keep the consistency of the precipitation, we use the extracted precipitation

2 information from the news to correct the M1-5d. The relationship between precipitation from

3 news and M1-5d is given in Eq. (1) and derived using a least-squares fitting method, as

4 presented in Fig. $4 \mathrm{~b}$, with $\mathrm{R}$ square 0.63 . The constructed curve allows us to transform the

5 precipitation in $\mathrm{CN} 05.1($ pre $(\mathrm{CN} 05.1))$ to the local precipitation as far as possible.
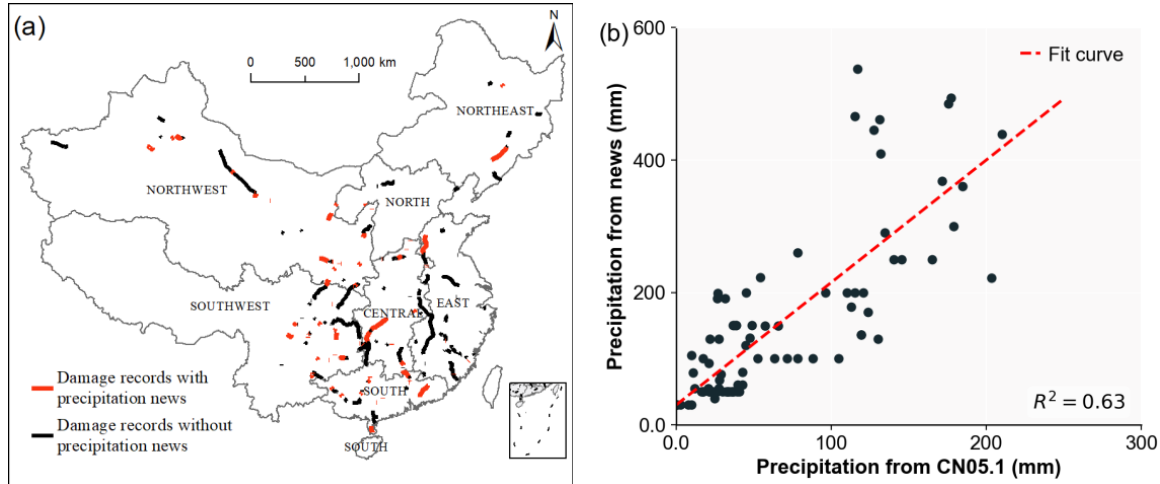

Fig. 4 (a) Spatial distribution of precipitation extracted from news and CN05.1; (b) The relationship between precipitation extracted from news and CN05.1.

\subsubsection{Calculation of the damage ratio}

The damage ratio is the ratio of the cost of repairing to the cost of rebuilding (Mazzorana et al., 2009), which is estimated by the news information and AUC-200D. First, we generate a custom damage ratio table based on the AUC-200D and the descriptive damage state is given in Sections 2.2 and 2.4. Second, we transform the descriptive damage state into a numerical damage ratio using the damage ratio table. There are three steps that we use to build the custom damage ratio table: 
1. Determine the cost ratio of the railway value for first-level structures. Based on AUC200D in Table 3, we calculate the cost ratio among four first-level structures. Taking the civil works: embankment as an example, the 'total cost' ratio is $0.65,0.25,0.09$, 0.1 for embankment track, signalling, communications and electrifications, respectively. For bridges and tunnels, the total cost ratios are shown in Appendix Table A2.

2. Classify the damage state for each first-level structure and give the numerical damage ratio range for each classification. The final damage states and the associated numerical ratio are divided into four classifications, namely, total damage (1), severe damage (0.66-0.99), moderate damage (0.33-0.66), and light damage (0.01-0.33), as shown in Table 4.

3. Calculate the numerical damage ratio range for a combination of a railway structure and a damaged state, and determine associated damage descriptive information based on news sources for each combination. The final damage ratio table is presented in Table 4, which is multiplied by the cost ratio of a first-level structure and the range ratio of the damage state classification. We then classify the damage state in sec 2.2 into each category.

Based on the damage ratio table and the historical news, we obtain the numerical damage ratio for each record. For each event, three damage ratios, namely, minimum ratio, average ratio, and maximum ratio, are obtained based on the damage ratio range. For example, the minimum ratio for the embankment's severe damage state is 0.644 , and the average and maximum ratios 
1 are 0.536 and 0.429 , respectively.

2 Table 4 Damage ratio table

\begin{tabular}{|c|c|c|c|c|}
\hline Element & $\begin{array}{c}\text { Unit cost } \\
\text { ratio }\end{array}$ & $\begin{array}{c}\text { Damage } \\
\text { state }\end{array}$ & Damage ratio & Description \\
\hline \multirow{4}{*}{ Embankment } & \multirow{4}{*}{0.6500} & Total & 0.6500 & Total damage \\
\hline & & Severe & $0.4290-0.6435$ & Suspended sleepers; Hanging rails \\
\hline & & Moderate & $0.2145-0.4290$ & $\begin{array}{l}\text { Subgrade shoulder, drainage ditch, side } \\
\text { drain, revetment slope protection, } \\
\text { protecting wall: moderate damage, } \\
\text { collapse }\end{array}$ \\
\hline & & Slight & $0.0065-0.2145$ & $\begin{array}{l}\text { Subgrade shoulder, drainage ditch, side } \\
\text { drain, revetment slope protection, } \\
\text { protecting wall: mild damage, cracks, } \\
\text { blockage, loose, wash out }\end{array}$ \\
\hline \multirow{4}{*}{ Track } & \multirow{4}{*}{0.1500} & Total & 0.1500 & Total damage \\
\hline & & Severe & $0.0990-0.1485$ & $\begin{array}{l}\text { Near-failure of components: sleepers, } \\
\text { rail, track bed }\end{array}$ \\
\hline & & Moderate & $0.0495-0.0990$ & $\begin{array}{c}\text { Two-component failure: sleepers, rail, } \\
\text { track bed }\end{array}$ \\
\hline & & Slight & $0.0015-0.4950$ & $\begin{array}{c}\text { Single-component failure: sleepers, } \\
\text { rail, track bed }\end{array}$ \\
\hline \multirow{3}{*}{$\begin{array}{l}\text { Signalling and } \\
\text { communications }\end{array}$} & \multirow{3}{*}{0.0900} & Total & 0.0900 & Total damage \\
\hline & & Severe & $0.0594-0.0891$ & $\begin{array}{l}\text { Near-destruction of components: } \\
\text { digital tuning and TDCS equipment }\end{array}$ \\
\hline & & Moderate & $0.0297-0.0594$ & $\begin{array}{l}\text { One-component destruction: digital } \\
\text { tuning and TDCS equipment }\end{array}$ \\
\hline
\end{tabular}




\begin{tabular}{|c|c|c|c|c|}
\hline & & Slight & $0.0009-0.0297$ & Communication equipment interrupted \\
\hline \multirow{4}{*}{ Electrification } & \multirow{4}{*}{0.1000} & Total & 0.1000 & Total damage \\
\hline & & Severe & $0.0660-0.0990$ & $\begin{array}{c}\text { Power supply equipment damage and } \\
\text { Catenary pillar destruction }\end{array}$ \\
\hline & & Moderate & $0.0330-0.0660$ & Power supply equipment damage \\
\hline & & Light & $0.0010-0.0330$ & Catenary pillar destruction \\
\hline
\end{tabular}

\section{$1 \quad$ 3.1.3 Fitting the vulnerability curves}

2 We choose the log-normal distribution to fit the vulnerability curve. The cumulative

3 distribution function of log-normal distribution is shown in Eq. 2,

4

5

6

$$
\mathrm{P}(\mathrm{x})=\varnothing\left[\frac{\ln (\mathrm{x} / \varphi)}{\xi}\right]
$$

which has two parameters, the location parameter $\varphi$ and the scale parameter $\xi$, namely, the median and standard values, respectively (Porter et al., 2007). We use the precipitation intensity as the $x$ value and the damage ratio as the $P(x)$ value. A log-normal vulnerability function is chosen because it is a parsimonious two-parameter distribution with positive support (ensuring that unrealistic negative loads cannot occur) and has many precedents for its use in fragility analysis (Porter et al., 2007).

In this study, we generate a total of seven vulnerability curves for the railway system: one for each of the six sub-regions (we combine North China into Central China since the damage records are less in North China), and one at the national level. To eliminate the noise and significant changes in the damage ratio, a moving average method is used to smooth the damage ratio in each precipitation intensity range. We use the criteria for classifying the precipitation intensity issued by the China Meteorological Administrator (2008), which is presented in Table 
15 , to apply the moving average method.

2 Table 5 Classification of the precipitation intensity

\begin{tabular}{|c|c|}
\hline Precipitation intensity & Total precipitation, in $\mathbf{2 4} \mathbf{~ h / m m}$ \\
\hline Light rain & $0.1-9.9$ \\
\hline Light rain-Moderate rain & $5.0-16.9$ \\
\hline Moderate rain & $10.0-24.9$ \\
\hline Moderate rain-Heavy rain & $17.0-37.9$ \\
\hline Heavy rain & $25.0-49.9$ \\
\hline Heavy rain-Torrential rain & $33.0-74.9$ \\
\hline Torrential rain & $50.0-99.9$ \\
\hline Torrential rain-Downpour & $75.0-174.9$ \\
\hline Downpour & $100.0-249.9$ \\
\hline Downpour-Heavy downpour & $175.0-299.9$ \\
\hline Heavy downpour & $\geq 250.0$ \\
\hline
\end{tabular}

\section{$3 \quad 3.2$ Risk assessment}

9 are used to calculate precipitation volumes per grid cell for selected return periods $(2,5,10,25$,

$1050,100,200,250,500$, and 1000 years). Precipitation volumes are calculated conditionally on

11 the exceedance probability of zero precipitation volume. For those cells where less than five

12 non-zero data points are available, the precipitation volume is assumed to be zero (Ward et al., 

system is expressed in Eq. 5 as follows:

$$
\mathrm{EAD}=\frac{1}{2} \sum_{\mathrm{r}=1}^{\mathrm{n}}\left(\frac{1}{\mathrm{~T}_{\mathrm{r}}}-\frac{1}{\mathrm{~T}_{\mathrm{r}+1}}\right)\left(\mathrm{D}_{\mathrm{i}}+\mathrm{D}_{\mathrm{r}+1}\right)
$$

where $T_{r}$ is the $r^{t h}$ return period, $D_{i}$ is associated with damage to the railway infrastructure, which is defined in Eqs. (4) and (5) :

$$
\begin{gathered}
D_{i}=\sum_{i}^{N} H_{r}^{i} * V * E_{i} * C_{\mathrm{DL}} \\
C_{\mathrm{DL}}=\frac{D L}{L}
\end{gathered}
$$
number of raster cells that intersect the railway line, and $C_{\mathrm{DL}}$ is a damage length factor for calibration. In Eq. 5, DL is the average damage length $(753 \mathrm{~m})$ per damage place in an event, and $L$ is the average railway length for all raster cells that intersect with railway lines. This study and previous studies assume that assets exposed in one raster cell are exposed to the same

19 damage degree for a certain hazard intensity. Based on the yearly railway damage data ( $\sec 2.3)$,

20 the average damage length in one damage place per event is $753 \mathrm{~m}$. This is much shorter

21 compared to the precipitation resolution (ca. $28 \mathrm{~km}$ ) used in this work and is also shorter than

22 the average railway length in each cell (ca. $14.6 \mathrm{~km}$ for double-track lines). We, therefore, 
1 introduce a damage length factor $\left(C_{\mathrm{DL}}\right)$ to calibrate the estimated damage, assuming that not

2 the entire railway section in a specific cell suffers damage from an event.

\section{4. Results}

\section{$4 \quad 4.1$ Vulnerability curves}

The national- and regional-level vulnerability curves are presented in Fig. 5. The upper boundary is the maximum vulnerability curve, the lower boundary is the minimum vulnerability curve, and the middle black line is the average vulnerability curve, fitted by maximum, minimum, and average ratios, respectively. Vulnerability curves have noticeable regional differences across the country. When considering relatively low precipitation intensities, railway lines in Northwest China are vulnerable to rainfall-induced hazards. Damage ratios in Northwest China are higher than other regional- and national-level damage ratios with the same precipitation intensity. For example, when the precipitation is $100 \mathrm{~mm}$ (torrential rain), the national railway damage ratio is 0.124 , whereas the railway damage ratio in Northwest China is about 0.148 . Railway lines in Northwest and Northeast China are particularly vulnerable to rainfall events with high precipitation intensities. In case of extensive precipitation of more than $200 \mathrm{~mm}$ (downpour), the national railway damage ratio is approximately 0.175 , the railway damage ratio in Northeast China is about 0.180 , and the railway damage ratio in Northwest China can reach 0.212 . In Northwest China, the precipitation amount over 100 years is less than $100 \mathrm{~mm}$. Considering the low frequency of extreme precipitation and the expensive cost of high protection standards, the Northwest China railway infrastructures are not robust relative to other areas when looking at the same precipitation. In Northeast China, the oldest railway lines, which 
1 have not been updated, have relatively low design standards and inadequate drainage facilities

2 to defend against extreme precipitation, resulting in higher vulnerabilities compared to other 3 regions.

\section{$9 \quad \mathbf{4 . 2}$ Risk analysis}

To incorporate the regional characteristics of the vulnerability for the Chinese railway system,

Fig. 5 National and regional vulnerability curves between precipitation (mm) and damage ratio. The maximum $R^{2}$ is the $R$ square for the maximum vulnerability curve, the average $R^{2}$ is the $R$ square for the average vulnerability curve, the minimum $R^{2}$ is the $R$ square for the minimum vulnerability curve.

we use the regional vulnerability curves to assess the risk of the Chinese railway system. We calculated the annual direct damage to railway infrastructure from 2000 to 2017, of which the results are presented in Fig. 6. The grey area is the range of annual direct damage, with the upper boundary calculated based on the maximum vulnerability curve, the lower boundary calculated based on the minimum vulnerability curve, and the middle darker grey line calculated based on the average vulnerability curve, thereby using the regional vulnerability curves. The darker yellow dots are the annual statistical damage in the yearbook with a $10 \%$

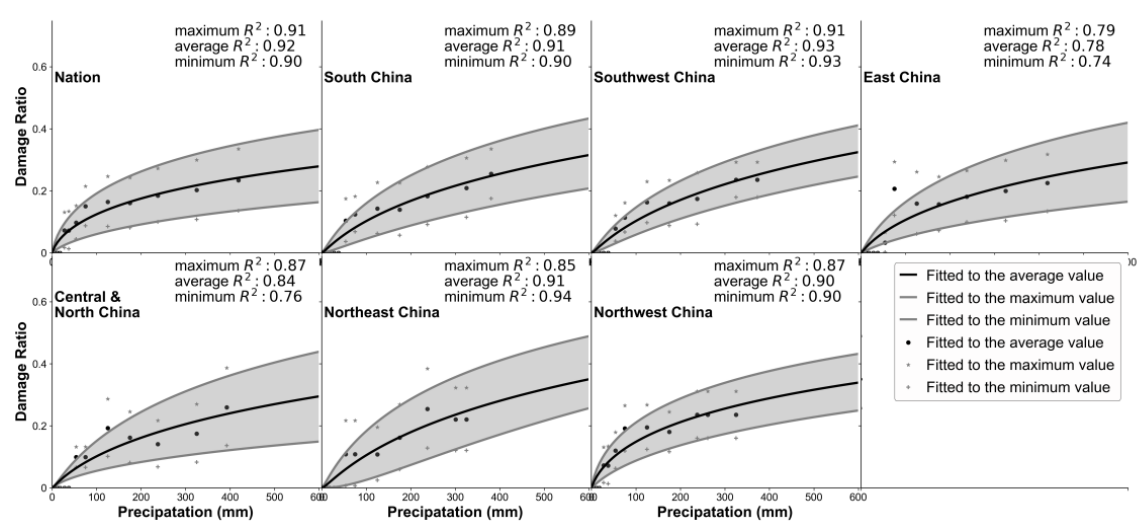


1 error scale. Compared to the statistical damage, we find that estimated damage is

2 underestimated for high annual damage and overestimated for small annual damage, which is

3 a consequence of using mean damage ratios for each precipitation range in the vulnerability

4 curves. Damage in 2000, 2001 and 2002 is overestimated, and the estimated damage is

5 calculated with the minimum vulnerability with $38 \%, 15 \%$ and $22 \%$ deviation from the

6 statistical damage. For the left, $81.25 \%$ of the statistically damaged points are located in the

7 estimated damage range. These results illustrate that the fitted vulnerability curves can be used

8 to calculate the damage.

9

10

13 The regional and national EAD to railway infrastructure due to rainfall-induced hazards are

14 presented in Fig. 7 using regional vulnerability curves. The national railway EAD is

Fig. 6 Annual direct damage due to damage to railway infrastructure from 2000 to 2017 in China.

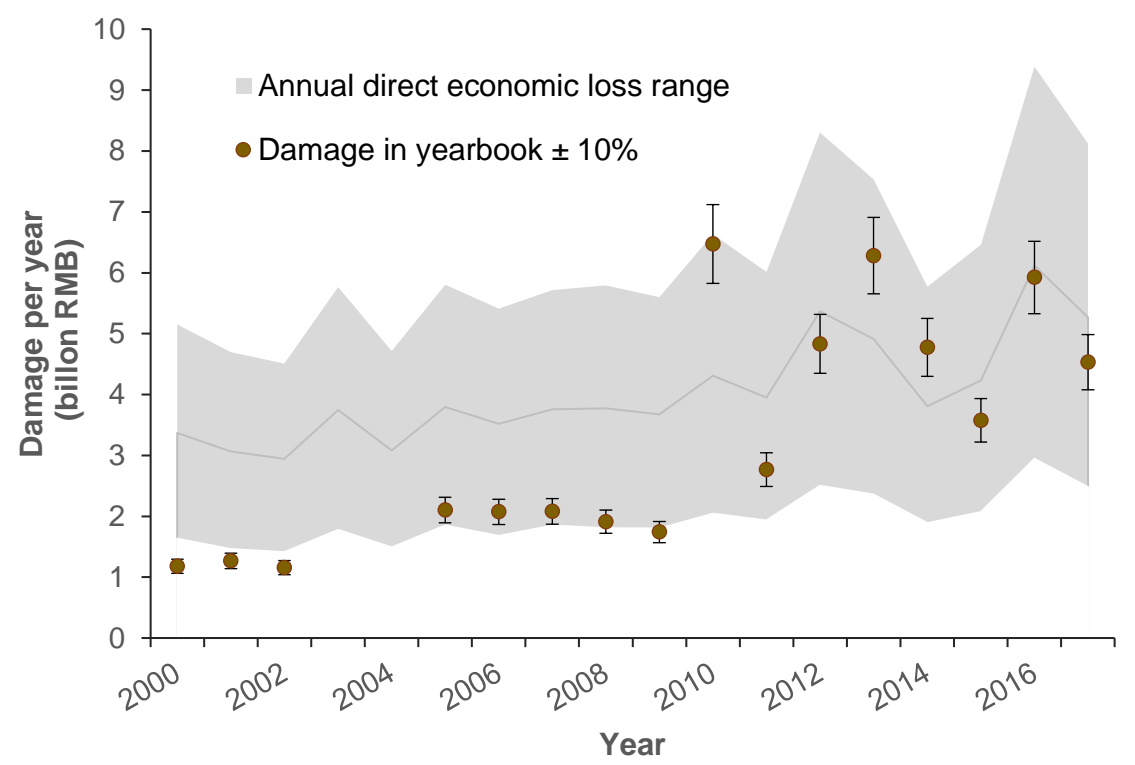


1 approximately 3.91 billion RMB when calculated with average vulnerability curves. When

2 calculated with minimum and maximum vulnerability curves, the national EAD is 1.88 billion

3 RMB and 5.98 billion RMB, respectively. Regionally, damage among areas differs substantially.

4 Using the results calculated with average vulnerability as an example, East China has the

5 highest risk with approximately 1.0 billion RMB, which exceeds the national EAD with $25.5 \%$.

6 North, South and Southwest China face a similar risk, with approximately 15\%, 14\%, and 13\%

7 of total national damage, respectively. High-density railway infrastructure exposure combined

8 with a high frequency of extreme precipitation in these regions results in railway infrastructure

$9 \quad$ with the highest risk.
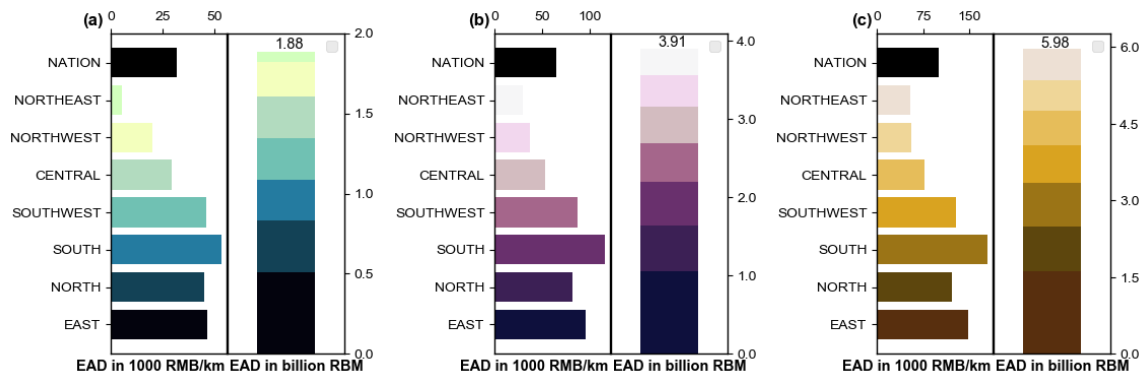

Fig. 7 Rainfall-induced hazard risk per region using different vulnerability curves. (a) The minimum vulnerability curve; (b) The average vulnerability curve; (c) The maximum vulnerability curve. The numbers on top of each stacked column chart are the national EAD values using the different vulnerability curves.

The national EAD per kilometre ranges from 32 to 86 thousand RMB, with an average of 65.38 thousand RMB using the average vulnerability curve. The EAD per kilometre is the highest in South China using the average vulnerability curves, which is 116.11 thousand RMB, followed by East China and Southwest China, for which the numbers are 96.30 and 87.37 thousand RMB, respectively. The railways in South, East and Southwest China require much 
1 attention and must improve their robustness.

2 The risk per province calculated using the regional average vulnerability curves of the

3 railway infrastructure to the rainfall-induced hazards are presented in Fig. 8. The risk differs considerably between regions when expressed in total EAD and EAD per kilometre. An examination of the total EAD shows that the provinces in North China, such as Hebei, Shanxi, Shandong, Henan, Southwest Sichuan and South Guangdong, experience the highest risks and is estimated to be larger than 200 million RMB. Hebei, Shandong have the most extended infrastructure assets in China. The railway in Shanxi and Sichuan are vulnerable to rainfall-

9 induced hazards, as shown in Fig. 5. When looking at EAD per kilometre for each province,

10 the provinces in Southwest China, such as Sichuan and coastal provinces(e.g. Guangdong,

11 Fujian, and Hainan), have the highest risks. The total EAD and EAD per kilometre are high in

12 Sichuan, Shanxi and Guangdong provinces. From the provincial perspective, these two

13 provinces need to allocate more resources to reduce the risk of rainfall-induced hazards.

(a) EAD per province [million RMB] $\triangle \mathrm{N}$

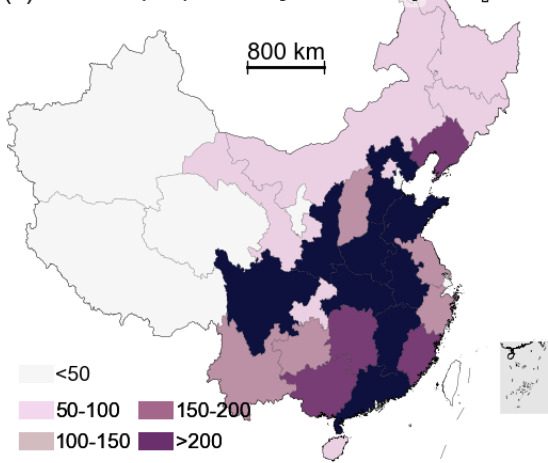

(b)EAD per km of each province [1000 RMB] $\triangle \mathrm{N}$

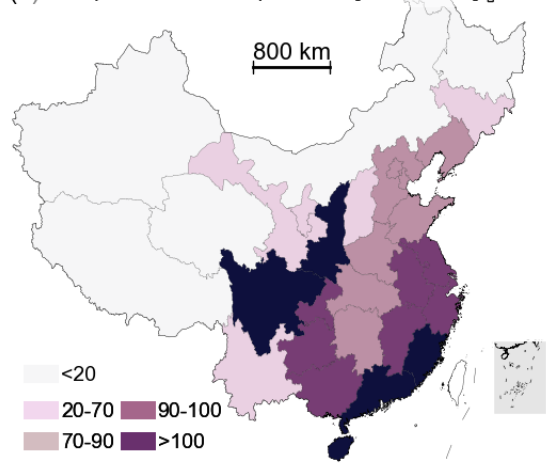

14

Fig. 8 Rainfall-induced hazard risk per province using the average vulnerability curve (a) EAD per province (million RMB) and (b) EAD per km of each province (1000 RMB). Fig.

A.1 provides a map of provinces of China. 


\section{5. Discussion}

This study uses multi-source empirical data to assess the vulnerability and risk to railway infrastructure in China associated with rainfall-induced hazards. For this purpose, the damage

4 news information and a custom damage ratio table are used to fit regional and national

5 vulnerability curves. Previous studies (e.g. Quan Luna et al., 2011; Papathoma-Köhle et al.,

6 2012; Silva and Pereira, 2014; Stephenson and D'Ayala, 2014; Tsubaki et al., 2016; Pregnolato

7 et al., 2017) have tried to use empirical data to fit the fragility or vulnerability curves to hazard

8 intensity and object damage ratio in some regions. In these studies, detailed photos (Papathoma-

9 Köhle et al., 2012; Pregnolato et al., 2017) or hazard model results (Quan Luna et al., 2011) are

10 mostly used to drive the hazard intensity, and adequate documentation of the damage and

11 reconstruction cost can be used to calculate damage ratios. Due to the strict requirement of

12 spatiotemporal damage and hazard intensity information, regional and national vulnerability

13 curves to link hazard characteristics and exposures are rare in many regions. This work tries to

14 overcome the universal problem of the lack of detailed vulnerability data. The fitted

15 vulnerability curves are used as the descriptive damage state in the information on damage and

16 precipitation derived from the news and exited precipitation dataset; these data are more easily

17 collected. Combining the fitted vulnerability curve, precipitation product, and railway

18 infrastructure exposure, the estimated risk of the national railway infrastructure, after

19 calibration with a damage length factor, is approximately 3.91 billion RMB. The overall railway

20 infrastructure risk results are broadly correlated with the yearbook average direct economic

21 damage from 2000 to 2017 , which is 3.29 billion RMB. The results reveal that vulnerability 
1 and risk can be estimated accurately using multi-source empirical data.

2 Several assumptions and limitations are acknowledged in this study. First, for damage

3 records without local precipitation information, we use the maximum daily precipitation 5 days

4 before damage occurrence (M1-5d) along the damaged segment to present the precipitation

5 intensity. However, there exists deviation for the local damage places along with the damaged

6 segments. In addition, the resolution of the CN05.1 precipitation data is too coarse to accurately

7 capture local extreme precipitation events. We hence use the extracted precipitation information

8 from the news to correct the M1-5d. In a certain way, it would decrease the uncertainty and

9 keep the consistency of the precipitation. Second, due to a lack of different railway market

10 values and detailed information on each railway infrastructure, this work uses the railway

11 market value for $200 \mathrm{~km} / \mathrm{h}$ railways of double tracks as the value for all types of railway

12 infrastructure. This leads to an overestimation of risk because most conventional railway speeds

13 are lower than $200 \mathrm{~km} / \mathrm{h}$, and the relative price has a high probability of being lower than 56

14 million RMB. Post-disaster reconstruction using higher design standards to improve railways'

15 ability to defend against disasters can reduce the risk for future hazards. data), the method used in this work can be a new direction to assess vulnerability and risk by combining multiple sources of empirical data. In addition, the low resolution of the spatiotemporal hazard map smooths the extreme values and cannot capture the hazardous

20 damage. Future research needs to develop a high-resolution spatiotemporal hazard map to 21 prevent this issue. 


\section{6. Conclusion}

In this study, we use multi-source empirical data to assess the vulnerability and risk to railway infrastructure in China associated with rainfall-induced hazards. Regional- and national-level precipitation vulnerability curves are derived based on news information and a custom damage ratio table. Based on precipitation data, fitted vulnerability curves, the market value of railway infrastructure, and a damage length factor, we assess and calibrate the annual direct damage from 2000 to 2017 caused by rainfall-induced hazards to Chinese railway infrastructure.

Due to the spatial unevenness of protection standards, the regional vulnerability curves of railway infrastructure to rainfall-induced hazards show high spatial inconsistency. Railways in South, Southwest, North, East, and Central China are robust to rainfall-induced hazards since higher protection standards have been used to defend the heaviest rainfall. Railways in Northwest and Northwest China are relatively vulnerable to rainfall-induced hazards. In addition, the regional curves generated in this study can be applied in other works after adjusting the length factor based on the methodology illustrated in sec 3.2.

The national railway infrastructure risk is approximately 3.91 billion RMB, and we find that the estimated annual direct damage of railway infrastructure to rainfall-induced hazards increases due to increasing extreme precipitation and railway exposure. Due to the spatially uneven precipitation intensity, exposure distribution and vulnerability curves, the risk in China show high spatial differences. The heaviest rainfall and high exposure density lead to a high absolute risk to railway infrastructure in South, East and Southwest China, even though they are robust to rainfall-induced hazards. Provinces such as Sichuan and Guangdong have high 
1 absolute and relative risks. For railway infrastructure risk reduction and sustainable

2 development of railway transportation in China, more attention and high protection standards

3 need to be allocated to these high-risk areas. This work provides regional and national

4 vulnerability and risk information for decision-makers.

\section{Code/Data availability}

6 Supporting data are accessible through the associated reference, and the historical railway

7 damage data used is in supplement material. The data in this study were analysed with Python

8 package, and the figures were created with ArcViewTM GIS and Python packages. All codes

9 used in this work are available upon request.

\section{Author contribution}

11 Kai Liu and Weihua Zhu developed the original idea and designed the analyses. Elco Koks

12 contributed to the study design. Weihua Zhu and Kai Liu conducted the analysis. Weihua Zhu

13 wrote the original manuscript, and Kai Liu, Ming Wang, Sadhana Nirandjan and Elco Koks

14 provided comments and revised the manuscript. All the co-authors contributed to scientific

15 interpretations of the results.

\section{Declaration of Competing Interest}

17 The authors declare that they have no known competing financial interests or personal

18 relationships that could have appeared to influence the work reported in this paper.

\section{Acknowledgements}

20 This work was supported by the National Natural Science Foundation of China [grant number 
141771538 ]; the National Key Research and Development Plan [grant number

2 2017YFC1502901]; and the National Key Research and Development Plan [grant number

3 2018YFC1508802]. The financial support is highly appreciated.

\section{Reference}

5 Cardoso Pereira, S., Marta-Almeida, M., Carvalho, A. C. and Rocha, A.: Extreme precipitation

6 events under climate change in the Iberian Peninsula, Int. J. Climatol., 40(2), 1255-1278,

7 doi:10.1002/joc.6269, 2020.

8 Diakakis, M., Boufidis, N., Salanova Grau, J. M., Andreadakis, E. and Stamos, I.: A systematic

9 assessment of the effects of extreme flash floods on transportation infrastructure and circulation:

10 The example of the 2017 Mandra flood, Int. J. Disaster Risk Reduct., 47(February), 101542,

11 doi:10.1016/j.ijdrr.2020.101542, 2020.

12 Editorial Board of China Railway Yearbook, Ed.: China railway yearbook, China Railway

13 Publishing House, Beijing., 2001.

14 Editorial Board of China Railway Yearbook, Ed.: China railway yearbook, China Railway

15 Publishing House, Beijing., 2009.

16 Englhardt, J., De Moel, H., Huyck, C. K., De Ruiter, M. C., Aerts, J. C. J. H. and Ward, P. J.:

17 Enhancement of large-scale flood risk assessments using building-material-based vulnerability

18 curves for an object-based approach in urban and rural areas, Nat. Hazards Earth Syst. Sci.,

19 19(8), 1703-1722, doi:10.5194/nhess-19-1703-2019, 2019.

20 Espinet, X., Rozenberg, J., Ogita, K. S. R. S., Singh Rao, K. and Ogita, S.: Piloting the Use of

21 Network Analysis and Decision-Making under Uncertainty in Transport Operations:

22 Preparation and Appraisal of a Rural Roads Project in Mozambique Under Changing Flood

23 Risk and Other Deep Uncertainties., 2018.

24 Gerald Ollivier, J. S. and N. Z.: High-Speed Railways in China: A Look at Construction Costs., 252014.

26 Habermann, N. and Hedel, R.: Damage functions for transport infrastructure, Int. J. Disaster

27 Resil. Built Environ., 9(4-5), 420-434, doi:10.1108/IJDRBE-09-2017-0052, 2018. 
Huizinga, J., de Moel, H. and Szewczyk, W.: Global flood depth-damage functions:

2 Methodology and the Database with Guidelines., 2017.

3 Jia, W. and Xuejie, G.: A gridded daily observation dataset over China region and comparison

4 with the other datasets, Chinese J. Geophys., 56(4), 1102-1111, 2013.

5 Jongman, B., Kreibich, H., Apel, H., Barredo, J. I., Bates, P. D., Feyen, L., Gericke, A., Neal,

6 J., Aerts, J. C. J. H. and Ward, P. J.: Comparative flood damage model assessment: Towards a

7 European approach, Nat. Hazards Earth Syst. Sci., 12(12), 3733-3752, doi:10.5194/nhess-12-

$8 \quad 3733-2012,2012$.

9 Kellermann, P., Schöbel, A., Kundela, G. and Thieken, A. H.: Estimating flood damage to

10 railway infrastructure - The case study of the March River flood in 2006 at the Austrian

11 Northern Railway, Nat. Hazards Earth Syst. Sci., 15(11), 2485-2496, doi:10.5194/nhess-15-

$12 \quad 2485-2015,2015$.

13 Kok, M., Huizinga, H., Vrouwenfelder, A. and Berendregt, A.: Damage and casualties caused 14 by flooding, 2004.

15 Koks, E. E., Rozenberg, J., Zorn, C., Tariverdi, M., Vousdoukas, M., Fraser, S. A., Hall, J. W.

16 and Hallegatte, S.: A global multi-hazard risk analysis of road and railway infrastructure assets,

17 Nat. Commun., 10(1), 1-12, doi:10.1038/s41467-019-10442-3, 2019.

18 Lamb, R., Garside, P., Pant, R. and Hall, J. W.: A Probabilistic Model of the Economic Risk to

19 Britain's Railway Network from Bridge Scour During Floods, Risk Anal., 20 doi:10.1111/risa.13370, 2019.

21 Li, L., Zou, Y., Li, Y., Lin, H., Liu, D. L., Wang, B., Yao, N. and Song, S.: Trends, change 22 points and spatial variability in extreme precipitation events from 1961 to 2017 in China, 23 Hydrol. Res., 51(3), 484-504, doi:10.2166/nh.2020.095, 2020.

24 Liu, K., Wang, M., Cao, Y., Zhu, W., Wu, J. and Yan, X.: A comprehensive risk analysis of transportation networks affected by rainfall-Induced multihazards, Risk Anal., 38(8), 16181633, doi:10.1111/risa.12968, 2018a.

27 Liu, K., Wang, M., Cao, Y., Zhu, W. and Yang, G.: Susceptibility of existing and planned

28 Chinese railway system subjected to rainfall-induced multi-hazards, Transp. Res. Part A Policy 
Pract., 117, 214-226, 2018b.

2 Liu, K., Wang, M. and Zhou, T.: Increasing costs to Chinese railway infrastructure by extreme

3 precipitation in a warmer world, Transp. Res. Part D Transp. Environ., 93(March),

4 doi:10.1016/j.trd.2021.102797, 2021.

5 Liu, W., Wu, J., Tang, R., Ye, M. and Yang, J.: Daily precipitation threshold for rainstorm and

6 flood disaster in the mainland of China: An economic loss perspective, Sustain., 12(1),

7 doi:10.3390/SU12010407, 2020.

8 Nadarajah, S.: The exponentiated Gumbel distribution with climate application, Environmetrics,

$9 \quad 17(1), 13-23,2010$.

10 Papathoma-Köhle, M., Keiler, M., Totschnig, R. and Glade, T.: Improvement of vulnerability 11 curves using data from extreme events: Debris flow event in South Tyrol, Nat. Hazards, 64(3), 12 2083-2105, doi:10.1007/s11069-012-0105-9, 2012.

13 Petrova, E.: Natural hazard impacts on transport infrastructure in Russia, Nat. Hazards Earth 14 Syst. Sci., 20(7), 1969-1983, doi:10.5194/nhess-20-1969-2020, 2020.

15 Pregnolato, M., Ford, A., Wilkinson, S. M. and Dawson, R. J.: The impact of flooding on road 16 transport: A depth-disruption function, Transp. Res. Part D Transp. Environ., 55, 67-81, 17 doi:10.1016/j.trd.2017.06.020, 2017.

18 Quan Luna, B., Blahut, J., Van Westen, C. J., Sterlacchini, S., Van Asch, T. W. J. and Akbas,

19 S. O.: The application of numerical debris flow modelling for the generation of physical 20 vulnerability curves, Nat. Hazards Earth Syst. Sci., 11(7), 2047-2060, doi:10.5194/nhess-11$21 \quad 2047-2011,2011$.

22 Sande, van der and C.J: River flood damage assessment using IKONOS imagery, Eur. Comm. 23 Jt. Res. Centre, Nat. Hazards Unit - Floods, Ispra (Va), ItalyEuropean Comm. Jt. Res. Centre, 24 Nat. Hazards Unit - Floods, Ispra (Va), Italy, (January 2001), 2001.

25 Shi, J., Cui, L., Wen, K., Tian, Z., Wei, P. and Zhang, B.: Trends in the consecutive days of 26 temperature and precipitation extremes in China during 1961-2015, Environ. Res., 161(July 27 2017), 381-391, doi:10.1016/j.envres.2017.11.037, 2018.

28 Silva, M. and Pereira, S.: Assessment of physical vulnerability and potential losses of buildings 
1 due to shallow slides, Nat. Hazards, 72(2), 1029-1050, doi:10.1007/s11069-014-1052-4, 2014.

2 Stephenson, V. and D'Ayala, D.: A new approach to flood vulnerability assessment for historic

3 buildings in England, Nat. Hazards Earth Syst. Sci., 14(5), 1035-1048, doi:10.5194/nhess-14-

$4 \quad 1035-2014,2014$.

5 Tsubaki, R., David Bricker, J., Ichii, K. and Kawahara, Y.: Development of fragility curves for

6 railway embankment and ballast scour due to overtopping flood flow, Nat. Hazards Earth Syst.

7 Sci., 16(12), 2455-2472, doi:10.5194/nhess-16-2455-2016, 2016.

8 Ward, P. J., Jongman, B., Weiland, F. S., Bouwman, A., Van Beek, R., Bierkens, M. F. P.,

9 Ligtvoet, W. and Winsemius, H. C.: Assessing flood risk at the global scale: Model setup,

10 results, and sensitivity, Environ. Res. Lett., 8(4), doi:10.1088/1748-9326/8/4/044019, 2013.

11 Yatagai, A., Arakawa, O., Kamiguchi, K., Kawamoto, H., Nodzu, M. I. and Hamada, A.: A 44-

12 year daily gridded precipitation dataset for Asia based on a dense network of rain gauges, Sci.

13 Online Lett. Atmos., 5(1), 137-140, doi:10.2151/sola.2009-035, 2009.

14 Zhang, X., Su, Z., Lv, J., Liu, W., Ma, M., Peng, J. and Leng, G.: A set of satellite-based near

15 real-time meteorological drought monitoring data over China, Remote Sens., 11(4), 1-12,

16 doi:10.3390/rs11040453, 2019.

17 Zhao, J., Liu, K. and Wang, M.: Exposure analysis of Chinese railways to multihazards based

18 on datasets from 2000 to 2016, Geomatics, Nat. Hazards Risk, 11(1), 272-287,

19 doi:10.1080/19475705.2020.1714753, 2020. 


\section{Appendix}

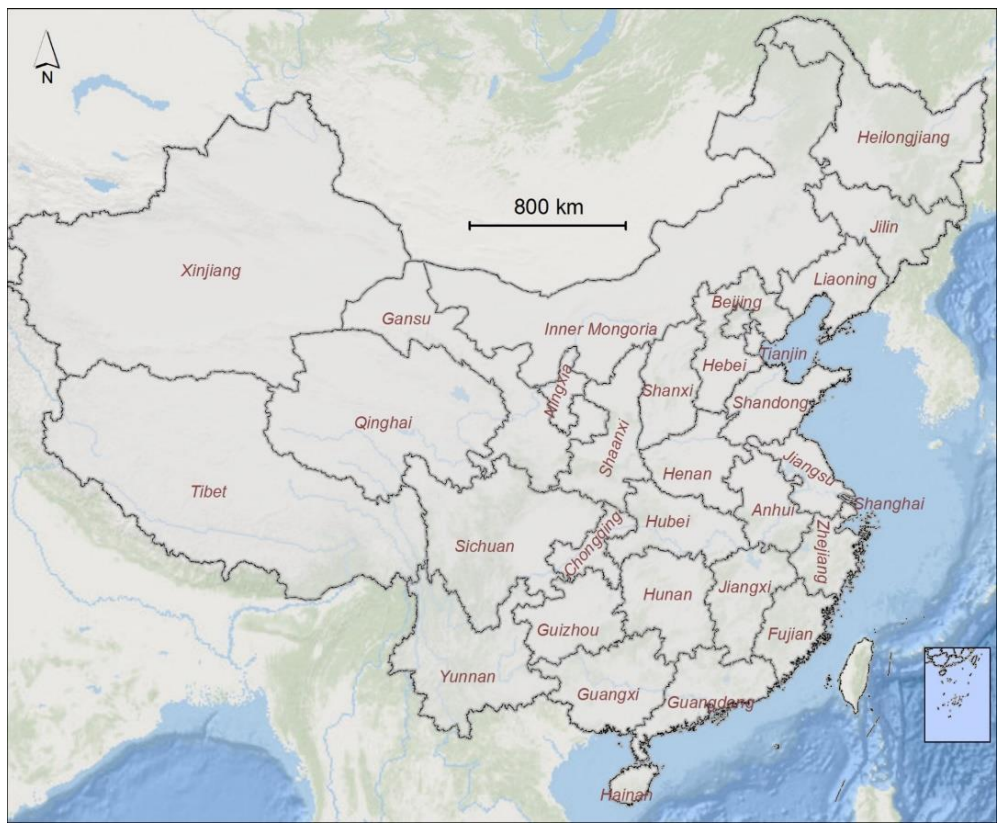

Fig. A.1 Map showing the distribution of Chinese provinces. The China Provincial Map layer comes from the Data Center for Resources and Environmental Sciences, Chinese Academy of

Sciences, which is accessible from the Resource and Environment Data Cloud Platform (http://www.resdc.cn/, last access: 19 May 2020).

Table A1 (a) Damage ratio table

\begin{tabular}{|c|c|c|c|c|}
\hline Element & $\begin{array}{c}\text { Unit cost } \\
\text { ratio }\end{array}$ & $\begin{array}{c}\text { Damage } \\
\text { state }\end{array}$ & Damage ratio & Description \\
\hline \multirow{3}{*}{$\begin{array}{c}\text { Bridges/viadu } \\
\text { cts }\end{array}$} & \multirow{3}{*}{0.8176} & Total & 0.8176 & Total damage \\
\hline & & Severe & $0.5396-0.8094$ & $\begin{array}{c}\text { Almost components destruction: } \\
\text { superstructure, bearing substructure and } \\
\text { accessory structure damage }\end{array}$ \\
\hline & & Moderate & $0.2698-0.5396$ & $\begin{array}{c}\text { Two-components destruction: } \\
\text { superstructure, bearing substructure and } \\
\text { accessory structure damage }\end{array}$ \\
\hline
\end{tabular}




\begin{tabular}{|c|c|c|c|c|}
\hline & & Slight & $0.0082-0.2698$ & $\begin{array}{c}\text { One-component destruction: } \\
\text { superstructure, bearing substructure and } \\
\text { accessory structure damage }\end{array}$ \\
\hline \multirow{4}{*}{ Track } & \multirow{4}{*}{0.0811} & Total & 0.0811 & Total damage \\
\hline & & Severe & $0.0535-0.0803$ & $\begin{array}{l}\text { Near-failure of components: sleepers, } \\
\text { rail, trackbed }\end{array}$ \\
\hline & & Moderate & $0.0268-0.0535$ & $\begin{array}{c}\text { Two-component failure: sleepers, rail, } \\
\text { trackbed }\end{array}$ \\
\hline & & Slight & $0.0008-0.0268$ & $\begin{array}{c}\text { Single-component failure: sleepers, rail, } \\
\text { trackbed }\end{array}$ \\
\hline \multirow{4}{*}{$\begin{array}{l}\text { Signalling and } \\
\text { communicatio }\end{array}$} & \multirow{4}{*}{0.0473} & Total & 0.0473 & Total damage \\
\hline & & Severe & $0.0312-0.0468$ & $\begin{array}{c}\text { Near-destruction of components: digital } \\
\text { tuning and TDCS equipment }\end{array}$ \\
\hline & & Moderate & $0.156-0.0312$ & $\begin{array}{l}\text { One-component destruction: digital } \\
\text { tuning and TDCS equipment }\end{array}$ \\
\hline & & Slight & $0.0005-0.0156$ & Communication equipment interrupted \\
\hline \multirow{4}{*}{ Electrification } & \multirow{4}{*}{0.0540} & Total & 0.0541 & Total damage \\
\hline & & Severe & $0.0357-0.0535$ & $\begin{array}{l}\text { Power supply equipment damage and } \\
\text { Catenary pillar destruction }\end{array}$ \\
\hline & & Moderate & $0.0178-0.0357$ & Power supply equipment damage \\
\hline & & Light & $0.0005-0.0178$ & Catenary pillar destruction \\
\hline
\end{tabular}

1

2 Table A1 (b) Damage ratio table

\begin{tabular}{|c|c|c|c|c|}
\hline Element & $\begin{array}{c}\text { Unit cost } \\
\text { ratio }\end{array}$ & $\begin{array}{c}\text { Damage } \\
\text { state }\end{array}$ & Damage ratio & Description \\
\hline \multirow{2}{*}{ Tunnels } & \multirow{2}{*}{0.8095} & Total & 0.8095 & Total damage \\
\hline & & Severe & $0.5379-0.8069$ & Almost components destruction: the \\
\hline
\end{tabular}




\begin{tabular}{|c|c|c|c|c|}
\hline & & & & $\begin{array}{c}\text { slope, portal, lining of portal and lining, } \\
\text { road or invert, surrounding rock of } \\
\text { Tube }\end{array}$ \\
\hline & & Moderate & $0.2690-0.5379$ & $\begin{array}{c}\text { Two of third of components } \\
\text { destruction: the slope, portal, lining of } \\
\text { portal and lining, road or invert, } \\
\text { surrounding rock of Tube }\end{array}$ \\
\hline & & Slight & $0.0082-0.2690$ & $\begin{array}{l}\text { One of third of component destruction: } \\
\text { the slope, portal, Lining of portal and } \\
\text { lining, road or invert, surrounding rock } \\
\text { of Tube }\end{array}$ \\
\hline \multirow{4}{*}{ Track } & \multirow{4}{*}{0.0794} & Total & 0.0822 & Total damage \\
\hline & & Severe & $0.0542-0.0814$ & $\begin{array}{c}\text { Near-failure of components: sleepers, } \\
\text { rail, track bed }\end{array}$ \\
\hline & & Moderate & $0.0271-0.0542$ & $\begin{array}{c}\text { Two-component failure: sleepers, rail, } \\
\text { track bed }\end{array}$ \\
\hline & & Slight & $0.0008-0.0271$ & $\begin{array}{c}\text { Single-component failure: sleepers, rail, } \\
\text { track bed }\end{array}$ \\
\hline \multirow{4}{*}{$\begin{array}{l}\text { Signalling and } \\
\text { communications }\end{array}$} & \multirow{4}{*}{0.0476} & Total & 0.0479 & Total damage \\
\hline & & Severe & $0.0316-0.0475$ & $\begin{array}{l}\text { Near-destruction of components: digital } \\
\text { tuning and TDCS equipment }\end{array}$ \\
\hline & & Moderate & $0.0158-0.0316$ & $\begin{array}{l}\text { One-component destruction: digital } \\
\text { tuning and TDCS equipment }\end{array}$ \\
\hline & & Slight & $0.0005-0.0158$ & Communication equipment interrupted \\
\hline \multirow{3}{*}{ Electrification } & \multirow{3}{*}{0.0635} & Total & 0.0548 & Total damage \\
\hline & & Severe & $0.0362-0.0542$ & $\begin{array}{l}\text { Power supply equipment damage and } \\
\text { Catenary pillar destruction }\end{array}$ \\
\hline & & Moderate & $0.0181-0.0362$ & Power supply equipment damage \\
\hline
\end{tabular}


https://doi.org/10.5194/nhess-2021-277

Preprint. Discussion started: 19 October 2021

(C) Author(s) 2021. CC BY 4.0 License.

$\begin{array}{r}\text { Natural Hazards } \\ \text { and Earth System } \\ \text { Sciences } \\ \hline \text { Discussions }\end{array}$

(c) (1)

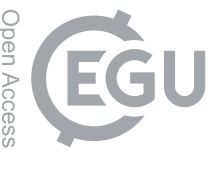

\begin{tabular}{|l|c|c|c|}
\hline & Light & $0.0005-0.0181$ & Catenary pillar destruction \\
\hline
\end{tabular}

1 